\title{
Weed suppression with grazing or atrazine during big bluestem establishment
}

\author{
B. KEITH LAWRENCE, STEVEN S. WALLER, LOWELL E. MOSER, BRUCE E. \\ ANDERSON, AND LARRY L. LARSON
}

\begin{abstract}
Anthors are family partner, Lawrence Farm and Ranch Supply, Cross Plains, Tex. 76443; professors, Depariment of
\end{abstract} Agronomy, and professor, Animal Science Deparment, University of Nebraska-Lincoln, Lincoln 68583-0915.

\begin{abstract}
Weed competition is a major factor causing warm-season grass seeding failures in rangeland and cropland. With a limited number of herbicides available for weed control, grazing may reduce competing vegetation in seedings and serve as an alternative to herbicides. Many immature weedy forbs and grasses are palatable to cattle and contain high nutrient levels. Research was conducted (RCBD, 4 reps) comparing grazing by yearling cattle with chemical suppression [atrazine (6-chloro-N-ethyl-N'(methylethyl)-1, 3, 5-triazine-2, 4-diamine)] for weed control in big bluestem (Andropogon gerardii var. gerardii Vitman) seedlings at Mead, Nebr. on a Sharpsburg silty clay loam (fine, montmorillonitic, mesic Typic Argiudoll) soil. Big bluestem was seeded at $220 \mathrm{PLS} \mathrm{m}^{-2}$ on 8 May 1987 and 25 April 1988. Weed contral practices were mob grazing, continuous stocking, earlyseason mob and continuous stocking, chemical suppression with atrazine (2.2 kg a.i. ha-1), and a control. Paddocks were mob grazed 4 times in 1987 and 2 times in 1988. Paddocks were continuously stocked from 10 June to 22 July 1987 . Continuous stocking was not attempted in 1988 because nitrate $\left(\mathrm{NO}_{3}{ }^{-}\right)$levels in redroot pigweed (Amaranthus retroflexus $\mathrm{L}$.) exceeded toxic levels ( 23,400 to $55,600 \mathrm{mg} \mathrm{kg}^{-1} \mathrm{NO}_{3}^{-}$) throughout the season. Acceptable big bluestem stands developed in 1987 and 1988, 14 and 6 plants $\mathrm{m}^{-2}$ respectively, on areas treated with atrazine. Density and frequency of big bluestem seedlings were lower on the atrazine-treated plots in 1988 due to higher levels of weed competition and reduced precipitation. Grazing treatments resulted in inadequate stands $\left(<1.0\right.$ plant $\left.\mathrm{m}^{-2}\right)$ of big bluestem in both years. Grazing is not a suitable alternative to chemical suppression for weed control for big bluestem establishment in subhumid and humid environments where high weed populations are common.
\end{abstract}

Key Words: Andropogon gerardii var. gerardii, seeding, atrazine, redroot pigweed, Amaranthus retroflexus, mob grazing, nitrate

\footnotetext{
At the time of the research, the senor unthor was a graduate research assistant, Department of Agronomy.

This manuscript has been assigned Journal Series No. 11030, Agricultural Research Diviston. University of Nebrashs. Manuscript accepted 24 Oct. 1994.
}

toxicity

Weed competition is a common reason for failed seedings of forage grasses (Bovey et al. 1986, King 1987). Grazing was a popular method of managing weeds in the first half of this century but was replaced with herbicides starting in the 1950's (Decker and Taylor 1985). Weed competition can be effectively reduced using herbicides (Martin et al. 1982, Bahler et al. 1984). Application of atrazine (6-chloro-N-ethyl-N'-(methylethyl)-1, 3, 5-triazine-2, 4-diamine) was a very effective weed control practice in the establishment of big bluestem (Andropogon gerardii var. gerardii Vitman) and switchgrass (Panicum virgatum L.) (Martin et al. 1982). Chemical methods of weed control, however, are often expensive and may be potentially harmful to the environment.

Weeds vary considerably in palatability. Studies have indicated that some weed species have high forage quality (Marten et al. 1987, Bosworth et al. 1980, Bosworth et al. 1985). Nitrate $\left(\mathrm{NO}_{3}{ }^{-}\right)$ accumulation, however, is often associated with certain weed species and poses a problem for grazing livestock. Redroot pigweed (Amaranthus retroflexus L.). a common weed species in Nebraska, is a $\mathrm{NO}_{3}^{-}$accumulator (Osweiler et al. 1985). The objective of this study was to compare grazing strategies to an effective method of chemical weed suppression in a big bluestem seeding.

\section{Materials and Methods}

\section{Study Site}

The study was conducted at the Agricultural Research and Development Center near Mead, Nebr. on a Sharpsburg silty clay loam (fine, montmorillonitic, mesic Typic Argiudoll) soil. The annual precipitation averages $690 \mathrm{~mm}$ with approximately $75 \%$ falling during the growing season (April-September). The frost free period is about 168 day $\mathrm{yr}^{-1}$. Precipitation from October 1986 through September 1987 was above normal (124\%). Precipitation was only $65 \%$ of normal from October 1987 through September 1988 and the spring was particularly dry.

The research area was a smooth brome (Bromus inermis Leyss.) pasture $(9 \mathrm{ha})$ that had received moderate manure appli- 
cations for several years. The study site was tilled and planted to corn (Zea mays L.) in 1985 and 1986. 'Pawnee' big bluestem was seeded (200 PLS m-2) on S May 1987 on one-half of the area following a double disking of the corn residue. The other half remained in corn until it was tilled and planted to Pawnee big bluestem (220 PLS m-2 on 25 April 1988.

\section{First Seeding Year}

In the 1987 seeding, 6 weed control practices (artazine application, continuous stockingl, early-season continuous stocking, mob grazing, early-season mob grazing, and no weed control) were applied to paddocks in a randomized complete block design with 4 replicates. The early-season grazing treatments were comparable to a pre-emergent weed control while the other grazing treatments were similar to pre- and postemergent. Atrazine was applied on $14 \mathrm{May}^{\prime}$ at $2.2 \mathrm{~kg}$ a.i. ha ${ }^{-1}$ (243 liters ha-1 water at 207 $\mathrm{k} \mathrm{Pa}$ ) before grass seedling emergence. Atrazine was selected to improve big bluestem establishment because it controls a broad spectrum of weeds. Martin et al. (1982) reported that big bluestem was tolerant to spring-applied, pre-emergent atrazine up to 3.4 a.i. $\mathrm{kg} \mathrm{ha}^{-1}$. Atrazine is no longer approved for grass establishment or rangeland renovation. One exception is in Nebraska where atrazine has been granted a special local needs registration for use on land enrolled in the Conservation Reserve Program and in warm-senson grass seed production fields.

Three cages $(1.2 \times 1.5 \times 0.6 \mathrm{~m})$ were randomly placed in each grazed paddock before grazing to determine establishment without weed control. Yearling dairy heifers $(275 \mathrm{~kg})$ were used to apply the grazing treatments. Continuous stocking (5 yearlings $0.20 \mathrm{ha}^{-1}$ ) occurred from 10 June to 22 July 1987 . Hay was fed as needed in the continuously stocked paddocks and water was provided. Cattle were removed from paddocks during wet conditions to prevent trampling damage to grass seedlings. Three additional cages were randomly placed in each continuously stocked paddock on 29 June 1987 to simulate the early-season, continuously stocked treatment. Mob grazing ( 10 yearlings $0.05 \mathrm{ha}^{-1}$ ) was accomplished 4 times $(10,16,22$ June and 20 July) in less than 24 hours per occupation. The early-season mob grazing treatment was created by randomly placing 3 cages on 29 June 1987 in the mob-grazed paddocks. Forage was grazed to a $5-\mathrm{cm}$ stubble height or until excessive trampling occurred in each grazed paddock.

\section{Second Seeding Year}

Four treatments (atrazine application, mob grazing, early-season mob grazing, and no weed control) were applied in a randomized complete block design with 4 replicates in 1988 . Atrazine was applied ( $2.2 \mathrm{~kg}$ a.i. ha-1) (243 liters ha-1 water at $207 \mathrm{kPa})$ on 6 May 1988 , before grass seedling emergence.

There was limited rainfall during the growing season of 1988 , which appeared to enhance $\mathrm{NO}_{3}^{-}$) accumulation in certain weedy species (Osweiler et al. 1985). Continuous stocking was not attempted due to potentially toxic $\mathrm{NO}_{3}^{-}$levels $\left(>10,000 \mathrm{mg} \mathrm{kg}^{-1}\right.$ $\mathrm{NO}_{3}{ }^{-}$) (Osweiler et al. 1985) in redroot pigweed and mob grazing was imposed only twice.

Management of the mob grazing plots was altered due to the

\footnotetext{
Terminolagy for grazing treatments follows the recommendations of the Fordge and Grazing Terminology Committee (1991).
}

extremely high $\mathrm{NO}_{3}^{-}$levels. Osweiler et al. (1985) indicated that $\mathrm{NO}_{3}{ }^{-}$concentration was generally greater in the stalk compared to the leaf. However, increased stock density for a short time period decreased stalk grazing and also reduced forage intake per animal. Consequently, a grazing strategy was designed to minimize stalk grazing. Grazing was restricted to less than 5 hours day $^{-1}$ and stocking density was increased to respond to the shorter grazing period. Yearling cross-bred steers [ $(345 \mathrm{~kg})$ (28 head $\left.0.05 \mathrm{ha}^{-1}\right)$ ] were used during the first mob grazing (28 June). Yearling cross-bred heifers [( $325 \mathrm{~kg})\left(24\right.$ head $\left.\left.0.05 \mathrm{ha}^{-1}\right)\right]$ were used during the second mob grazing ( 7 July).

Cages $(1.2 \times 1.5 \times 0.6 \mathrm{~m})$ were randomly placed in all grazed paddocks to determine establishment without weed control. Three more cages were placed in the mob-grazed paddocks on 29 June to create the early-season mob grazing treatment.

\section{Sampling}

Redroot pigweed was sampled each year during the study to monitor $\mathrm{NO}_{3}^{-}$levels. Plant material $(500 \mathrm{~g})$ representative of available forage (excluding the lower $15 \mathrm{~cm}$ based on observed animal preference) was randomly collected across all treatments and composited at each sample date in 1987. Due to high $\mathrm{NO}_{3}{ }^{-}$ levels and leaf stripping by cattle, leaves and stems were sampled separately in 1988. Samples were collected 6 times in 1987 (11, 16,23 June and 6, 16, 22 July) and 5 times in $1988(14,20,28$ June and 7,25 July). Multiple replicates were sampled when stage of growth varied across block. The $\mathrm{NO}_{3}{ }^{-}$ion was determined using a $\mathrm{NO}_{3}^{-}$electrode (Carlson and Paul 1969). Weed density was sampled on 2 June 1988 to determine plant density and frequency. Fifteen samples $(30 \times 60 \mathrm{~cm})$ were sampled in each paddock.

Big bluestem seedling density (plants $\mathrm{m}^{-2}$ ) was determined by randomly placing a $1-\mathrm{m}$ rod parallel to the drill row and counting the number of seedlings along the rod. Seedling success was ranked according to the following scale: failure $\left(<5\right.$ seedlings $\left.\mathrm{m}^{2}\right)$,

Tahle 1. Density (seedlings $\mathrm{m}^{-2}$ ) and frequency (\%) of big bluestem seeded near Mead, Nebr. on 8 May 1987 or 25 April 1988 and sampled fall 1987 and 1988 , respectively.

\begin{tabular}{|c|c|c|c|c|}
\hline \multirow[b]{2}{*}{ Trentment } & \multicolumn{2}{|c|}{ Density } & \multicolumn{2}{|c|}{ Frequency } \\
\hline & 1987 & 1988 & 1987 & 1988 \\
\hline & \multicolumn{2}{|c|}{$\ldots\left(\right.$ seedlings $\left.\mathrm{m}^{-2}\right) \ldots$} & \multicolumn{2}{|c|}{$\cdots(\%)-\ldots$} \\
\hline Atrazine (ATZ) & 13 & 6 & 44 & 23 \\
\hline $\begin{array}{l}\text { Continuously } \\
\text { stocked (CS) }\end{array}$ & $<1$ & -1 & $<1$ & - \\
\hline $\begin{array}{l}\text { Early-season } \\
\text { continuously } \\
\text { stocked (ECS) }\end{array}$ & 0 & - & 0 & - \\
\hline $\begin{array}{l}\text { Mob } \\
\text { grazed (MG) }\end{array}$ & $<1$ & $<1$ & $<1$ & 2 \\
\hline $\begin{array}{l}\text { Early-season } \\
\text { mob grazed (EMG) }\end{array}$ & 0 & 0 & 0 & 0 \\
\hline Control (CTL) & $<1$ & 0 & 0 & 0 \\
\hline \multicolumn{5}{|c|}{ - - - Single degree of freedom contrasts (Pr>F)- - . } \\
\hline ATZ rs CS. MG ${ }^{2}$ & $<0.01$ & & $<0.01$ & \\
\hline MG vs CS & 0.73 & & 0.72 & \\
\hline ATZ vS CTL & $<0.01$ & $<0.01$ & $<0.01$ & $<0.01$ \\
\hline CTL vs MG & & 0.54 & & 0.53 \\
\hline ATZ vs MG & & $<0.01$ & & $<0.01$ \\
\hline
\end{tabular}

Treatment not applied in 1988.

2Comparison of the atracine Ireatment to the averaged reyponse of continuously stocked (CS) and the mob grazed (MG) trealments. 
marginal (5-10 seedlings $\mathrm{m}^{-2}$ ), successful ( $>10$ seedlings $\mathrm{m}^{-2}$ ), (Launchbaugh 1966. Launchbaugh and Owensby 1978). Seedling frequency was determined by dividing the $1-\mathrm{m}$ rod into $20-\mathrm{cm}$ segments. Frequency (percentage of segments occupied by at least 1 big bluestem seedling) indicated seedling distribution along the drill row. Number of samples was determined using Stein's two-stage sample (Stecl and Torrie 1980). Sampling of the 1987 seeding was completed on 27 September 1987 (54 samples) and 9 June 1988 ( 70 samples). The 1988 seeding was sampled ( 70 samples) on 28 October 1988 and 6 June 1989. Data was converted into seedlings $\mathrm{m}^{-2}$ and tested for normality of distribution (Stroup et al. 1986). Selected single degree of freedom contrasts were used to determine treatment differences.

\section{Results and Discussion}

Past cultural practices resulted in a dense population of redroot pigweed, annual foxtails (giant foxtail (Setaria faberi Herrm.), yellow foxtail [S. lutescens (Weigel) Hubb.], bristly foxtail [S. verticillata (L.) Beauv.], and green foxtail [S. viridis (L.) Beauv.]\}, velvetleaf (Abutilon theophrasti Medic.), and common ragweed (Ambrosia artemisifolia L.). Redroot pigweed and the foxtails were palatable, and crude protein $(\mathrm{CP})$ and in vitro dry matter disappearance (IVDMD) levels were similar to early-vegetative smooth brome or early-bloom alfalfa (Medicago sativa $\mathrm{L}$.) hay (Lawrence et al. 1989). However, redroot pigweed accumulated $\mathrm{NO}_{3}{ }^{-}$above toxic levels. Velvetleaf and common ragweed also had similar CP and IVDMD values, but low palatability restricted utilization.

\section{First Seeding Year}

Big bluestem seedling density and frequency at the end of the seeding year were higher $(P<01)$ (Table 1$)$ in the atrazine treatment than in the other treatments. Foxtails were suppressed by atrazine until mid-summer, after big bluestem had established. Big bluestem seedling establishment on the atrazine-treated plots was successful ( $>10$ seedlings $\mathrm{m}^{-2}$ ) Overwinter survival of seedlings in the atrazine-treated paddocks was acceptable $(9$ plants $\mathrm{m}^{-2}$ ) compared to 13 seedlings $\mathrm{m}^{-2}$ at the end of the seeding year.

Big bluestem stands were poor $\left(<5\right.$ plants $\left.\mathrm{m}^{-2}\right)$ in all grazing treatments at the end of the seeding year (Table 1). Weed competition was not effectively reduced by grazing. Yearling heifers grazed annual foxtails and redroot pigweed but did not graze velvetleaf and common ragweed. There was no evidence of acute $\mathrm{NO}_{3}{ }^{-}$poisoning even though whole-plant $\mathrm{NO}_{3}{ }^{-}$concentrations in redroot pigweed were above the potentially toxic level $(10,000$ $\mathrm{mg} \mathrm{kg}{ }^{-1} \mathrm{NO}_{3}^{-}$).

Cattle were removed from paddocks for a 9-day period after a heavy rain in late June. Regrowth of annual foxtails and redroot pigweed and emergence was so rapid during this period that cattle could not reduce weed competition when grazing resumed. Cattle did not trample velvetleaf in mob grazing treatments, resulting in a tall, weed canopy that shaded the soil surface. This increased the time required to dry the soil surface and delayed the return of livestock. There was no difference in plant density between the end of the seeding year and following spring for continuously stocked, mob grazed, or control paddocks $\left(<1\right.$ plant $\left.\mathrm{m}^{-2}\right)$.

\section{Second Seeding Year}

Seedling density in the atrazine treatment was marginal (5 to 10 plants $\mathrm{m}^{-2}$ ) (Table 1). Frequency data indicated a more discontinuous stand than in 1987. Below normal rainfall for the entire season contributed to the low seedling density and frequency of big bluestem in the 1988 atrazine treatment compared to 1987. Also, atrazine apparently did not control early germination of foxtails as effectively as in 1987. There was no measurable overwinter stand loss in the atrazine-treated paddocks with 6 big bluestem plants $\mathrm{m}^{-2}$ in 1989.

Seedlings failed to establish in either the control or the earlyseason mob grazing treatment while the mob-grazed treatment was not significantly different from the control (Table 1). There werc no established plants identified in 1989 on the early-season mob grazed or the control. The mob-grazed paddocks had $<1$ big bluestem plant $\mathrm{m}^{-2}$ in the spring of 1989.

Redroot pigweed was the dominant forage species and total weed density was high in grazed paddocks (129 plants $\mathrm{m}^{-2}$ ). Velvetleaf and common ragweed were not as abundant in 1988 as in 1987. Nitrate accumulation prevented timely grazing in 1988. Initial grazing was delayed because of the potentially toxic $\mathrm{NO}_{3}{ }^{-}$ level in redroot pigweed.

The importance of weed control for the successful establishment of warm-season grasses in a humid-subhumid environment was evident from this study. Grazing with cattle was not an acceptable alternative to chemical suppression. Density and biomass of weed populations were too great to be suppressed by grazing. Apparent differential palatability of weed species coupled with a light to moderate stocking rate resulted in selective grazing and ineffective weed control.

The timeliness of weed defoliation was often influenced by excessive soil surface moisture and $\mathrm{NO}_{3}{ }^{-}$accumulations in palatable weed species interferred with timing of grazing. It was not possible during this 2-year trial to maintain consistent and effective grazing pressure. Cattle had to be removed when wet conditions increased potential for damaging seedlings by trampling. Weed biomass increased beyond the grazing capacity during this period of nonuse. Redroot pigweed was a preferred species that also accumulated $\mathrm{NO}_{3}{ }^{-}$. Nitrate toxicity is a common problem with most weed populations that is aggravated by dry conditions. During 1988, cattle had to be removed several times due to excessive $\mathrm{NO}_{3}{ }^{-}$levels in the weeds. These characteristics limit the use of cattle grazing as an alternative weed control practice in humid and subhumid areas, even if species have high palatability.

Weed control is important for big bluestem establishment. Chemical suppression of weeds resulted in acceptable stands in both a wet and a dry growing season. Grazing did not provide an effective alternative to reduce weed competition for big bluestem establishment. The presence of redroot pigweed, a palatable $\mathrm{NO}_{3}{ }^{-}$ accumulator, compromised the ability to graze with cattle for weed control. Surface soil moisture also influenced grazing, often jeopardizing the timeliness of weed defoliation. Effective, environmentally sound herbicides must be developed to provide adequate weed suppression in warm-season grass seedings.

\section{Literature Cited}

Bahler, C.C., K.P. Vogel, and L.E. Moser. 1984. Atrazine tolerance in warm-season grass seedlings. Agron. J. 76:891-\$95.

Bosworth, S.C., C.S. Hoveland, and G.A. Buchanan. 1985. Forage quality of selected cool-season weed rpcies. Weed Sci. 34:150-154. 
Bosworth, S.C., C.S. Hoveland, G.A. Buchanan, and W.B. Anthony. 1980. Forage quality of selected warn-season weed species. Agron. J. $72: 1050-1054$

Bovey, B.W., R.E. Meyer, M.G. Merkle, and E.C. Bashaw. 1986. Effect of herbicides and handweeding on establinhment of kleingrass and buffelgrass. J. Range Mranage. 39:547-551.

Carlson, R.M., and J.L. Paul. 1969. Nitrate determination of plant extracts by nitrate electrode. J. Agr. Food Chent. 16:766.

Decker, A.M., and T.H. Taylor. 1985. Establishment of new seeding and renovation of old sod, p. 2S8-297. $m$ : M E. Heath, R.F. Barnes, and D.S. Metcalfe (eds.), Forages, the science of grassland agriculture. Iowa State Univ. Press, Ames, Iowa.

Forage and Grazing Terminology Committee. 1991. Terminology for grazing lands and grazing animals. Pocahontas Press, Inc., Blackburg. Virg.

King, M.A. 1987. Establishment of forage grasses on abandoned Sandhills cropland. MS Thesis. Univ. of Nebraskú-Lincoln, Lincoln, Nebr.

Launchbaugh, J.L. (ed.) 1966. A stand estublishment survey of grass planting in the Great Plains. Nebraska Agr. Exp. Sta. Great Plains Agr. Coune. Pub 23.
Launchbaugh, J.L., and C.E. Owensby. 1978. Kansas rangelands-their management based on a half century of research. Kansas Agr. Exp. Sta. Bull. 622 .

Lawrence, B.K., S.S. Waller, L.E. Moser, B.E. Anderson, and L.L. Larson. 1989. Forage value of weed species in grass seedings, p. 91-94. In: T.B. Bragg and J. Stubbendieck (eds.), Proc. North Amer. Prairie Conf. Lincoln. Neb.

Marten, G.C., C.C. Sheaffer, and D.L. Wyse. 1987. Forage nutrituve value and palatability of perennial weeds. Agron. J. 79:980-986.

Martin, A.R., R.S. Moomaw, and K.P. Vogel. 1982. Warm-season grass establishment with atrazine. Agron. J. 74:916-920.

Osweiler, G.D., T.L. Carson. W.B. Buck, and G.A. Van Gelder. 1985. Clinical and diagnostic veterinary toxicology. Kendall/Hunt Pub. Co. Dubuque, lowa.

Steel, R.G.D., and J.H. Torrie. 1980. Principles and procedures of statjstics, a biometrical approach. McGraw-Hill, N.Y.

Stroup, W.W., S.S. Waller, and R.N. Gates. 1986. Exposition on the selection of appropriate experimental design and statistical analysis for pasture improvement research. J. Range Manage. 39:200-206. 